\title{
Contents, Vol. 190, 1985
}

No. 1 In memoriam Jules Francois 1

Original Paper - Travaux originaux Originalarbeiten

Combined Perforating Keratoplasty and Intracapsular Cataract Extraction

Sautter, H.; Demeler, U

2

Quantitative Monitoring of Fundus Changes

Miszalok, V.; Burkhardt, R.; Wollensak, J 7

Indocyanine Green Angiography of Submacular Choroidal Vessels in the Human Eye

Hayashi, K.; de Laey, J.J 20

Indocyanine Green Angiography of Choroidal Neovascular Membranes

Hayashi, K.; de Laey, J.J 30

Retinal Detachment during Glaucoma Therapy. Review. A Case Report of an Occurrence of

Retinal Detachment after Using Membranous Pilocarpine Delivery System [Pilokarpin

Lameller (Ocusert®) $11 \mathrm{mg}]$

Puustjärvi, $T \quad 40$

Light and Electron Microscopical Study of the Conjunctiva in Sicca Syndrome

Meyer, E.; Scharf, Y.; Schechner, R.; Zonis, S.; Scharf, Y.; Nahir, M

Clinicopathologic Case Report Description clinico-pathologique de cas -Klinisch-pathologische

Fallbeschreibung

Inkompletter Zentralvenenverschluss. Ein klinisch-pathologischer Fallbericht

Lücke, A.; Landolt, E 53

Book Reviews · Livres nouveaux Buchbesprechungen

No. 2 In memoriam Hans Sautter 65

Original Paper - Travaux originaux - Originalarbeiten

Association d'un lipodermoïde épibulbaire à une alopécie et un nævus verruqueux sébacé:

syndrome malformatif congenital à hérédité hologyne

Streiff, E.B.; Zografos, L

67

Kératopathie dans la maladie de Crohn. Etude d'un cas au microscope électronique

van Vliet, A.A.; van Balen, A.Th.M 72

Fluorescein Angiography in Inflammation of the Peripheral Fundus: The Normal Fluorescein

Angiographic Pattern. I

Zenker, H.-J 77

Primary Meningioma of the Optic Nerve Sheaths: Case Report

Probst, Ch.; Gessaga, E.; Leuenberger, A.E 83

Fibröse Dysplasie der knöchernen Orbita mit «Neuritis retrobulbaris»

Gornig, H.; Goldhahn, W.-E.; Schmidt, F.; Arendt, A

Ocular Tension: Comparison between the Two Eyes

Carel, R.S.; Korczyn, A.D.; Rock, M 98

Index III

Calcium Dobesilate in Diabetic Retinopathy. A Retrospective Controlled Study 
Adank, Ch.; Koerner, F

102

Nd-YAG Laser in Our Experience (with 2 color plates)

Balacco-Gabrieli, C; Avolio, G.; Lorusso, V.V.; Castellano, L

Standard Pseudoisochromatic Plates part 2

Pinckers, A.; Nabbe, B.; Vossen, H 118

Clinicopathologic Case Report · Description clinico-pathologique de cas · Klinisch-

pathologischeFallbeschreibung

Adenoid Cystic Carcinoma of the Orbit Diagnosed by Means of Aspirative Cytology

Malberger, E.; Gdal-On, M 125

Announcement $\cdot$ Communication · Ankündigung 124

Book Review $\cdot$ Livre nouveau - Buchbesprechung 128

No. 3 Original Paper · Travaux originaux Originalarbeiten

Zur Diagnostik des Melanoma uveae

Trinkmann, R 129

Zentrale chorioretinale Dystrophie mit Drusen und retinalen Kristallen

Weber, U.; Adler, K.; Hennekes, R 134

Fluorescein Angiography in Inflammation of the Peripheral Fundus: Involvement of the

Choroid and Retina. II

Zenker, H.-J.; Klein, S

Tear Water Evaporation and Eye Surface Diseases

Rolando, M.; Refojo, M.F.; Kenyon, K.R 147

Retinal Pigment Epithelial Dysfunction in Early Ovine Ceroid Lipofuscinosis: Electrophysiologic and Pathologic Correlates

Samuelson, D.; Dawson, W.W.; Webb, A.I.; Dowson, J.; Jolly, R.; Armstrong, D. . 150

Clinicopathologic Case Report · Description clinico-pathologique de cas $\cdot$ Klinisch-

pathologischeFallbeschreibung

Solitary Astrocytic Hamartoma Simulating Retinoblastoma

Drewe, R.H.; Hiscott, P.; Lee, W.R 158

Proceedings - Comptes rendus - Verhandlungsberichte

Netherlands Ophthalmological Society. 178th Annual Meeting, March 29-31, 1984,

's-Hertogenbosch 168

Book Reviews $\cdot$ Livres nouveaux $\cdot$ Buchbesprechungen 189

Erratum 192

No. 4 Original Paper · Travaux originaux $\square$ Originalarbeiten

Secondary Fuchs's Heterochromic Cyclitis: a New Approach to an Old Disease

Saraux, H.; Laroche, L.; Le Hoang, P 193

Beeinflussung der retinalen Hämodynamik durch Anderung des Augeninnendruckes: eine videoangiographische Studie

Richard, G 199

IV

Index

Fluorescein Angiography in Inflammation of the Peripheral Fundus: Involvement of the

Pars plana corporis ciliaris. Ill

Zenker, H.-J 205

Choroidal (Subretinal) Neovascularization Secondary to Choroidal Nevus and Successful

Treatment with Argon Laser Photocoagulation. Case Reports and Review of Literature 
Mines, J.A.; Freilich, D.B.; Friedman, A.H.; Lazar, M

Clinical Observations Concerning Choroidal Folds

Steuhl, K.P.; Richard, G.; Weidle, E.G 219

Intraocular Ossification

Monselise, M.; Rapaport, I.; Romem, M.; Barishak, Y.R 225

Orbital Pseudotumor: Histopathological Classification and Treatment

Fujii, H.; Fujisada, H.; Rondo, T.; Takahashi, T.; Okada, S 230

Clinicopathologic Case Report - Description clinico-pathologique de cas -Klinisch-

pathoIogischeFallbeschreibung

Filaria conjunctivae

Orsoni, J.G.; Coggiola, G.; Minazzi, P 243

Book Reviews · Livres nouveaux · Buchbesprechungen

Author Index 249

Subject Index 251

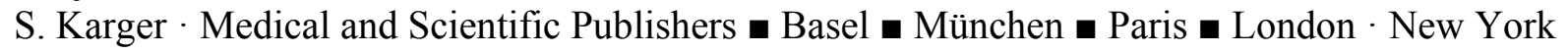

- Tokyo a Sydney

Drug Dosage

The authors and the publisher have exerted every effort to ensure that drug selection and dosage set forth in this text are in accord with current recommendations and practice at the time of publication. However, in view of ongoing research, changes in government regulations, and the constant flow of information relating to drug therapy and drug reactions, the reader is urged to check the package insert for each drug for any change in indications and dosage and for added warnings and precautions. This is particularly important when the recommended agent is a new and/or infrequently employed drug.

All rights reserved.

No part of this publication may be translated into other languages, reproduced or utilized in any form or by any means, electronic or mechanical, including photocopying, recording, microcopying, or by any information storage and retrieval system, without permission in writing from the publisher or, in the case of photocopying, direct payment of a specified fee to the Copyright Clearance Center (see 'Information for Readers and Subscribers').

(C) Copyright 1985 by

S. Karger AG, P.O. Box, CH-4009 Basel (Switzerland)

Printed in Switzerland by

Buchdruckerei Friedrich Reinhardt AG, Basel 